\title{
Spotkanie Zespołu Pedagogiki Ogólnej (Warszawa, 4 listopada 2016 r.)
}

Zespół Pedagogiki Ogólnej działający przy Komitecie Nauk Pedagogicznych (KNP) Polskiej Akademii Nauk (PAN) spotkał się 4 listopada w Akademii Pedagogiki Specjalnej im. Marii Grzegorzewskiej w Warszawie (APS). Na spotkanie przybyło ponad 20 pedagogów reprezentujących ośrodki naukowe z całego kraju. Obradom przewodniczył Roman Leppert. Zebranych powitał JM Rektor APS i jednocześnie wiceprzewodniczący KNP Stefan Kwiatkowski. W krótkim wystąpieniu zwrócił uwagę na postępującą dywersyfikację subdyscyplin pedagogicznych, która wynika z rosnącego poziomu wyspecjalizowania poszczególnych obszarów działania pedagogicznego. Na tym tle naglącą potrzebą staje się, jego zdaniem, ponowne odkrycie pedagogiki ogólnej jako „królowej pedagogik szczegółowych”, do której zadań należy kultywowanie więzi łączących wielorakie i nieredukowalne zakresy wiedzy pedagogicznej.

W części wprowadzającej członkowie ZPO złożyli gratulacje Romanowi Leppertowi z powodu uzyskania tytułu profesora. Dziękując, przewodniczący ZPO zapewnił, że swoją nominację uznaje za wyraz dowartościowania przez polskie środowisko pedagogiczne dyscypliny, którą reprezentuje, czyli pedagogiki ogólnej, i że dołoży wszelkich starań, żeby to uznanie wspólnym wysiłkiem nadal umacniać i rozbudowywać. Potem przedstawił program bieżącego spotkania zespołu.

Najpierw zebrani wysłuchali referatu Jarosława Gary z Katedry Podstaw Pedagogiki Instytutu Pedagogiki APS pt. Fenomenologiczna kategoria świata życia codziennego jako przesłanka eksplikacji sensów edukacji. Mówca skupił się na czterech pytaniach: 1 . Co to jest fenomenologia i jaki jest jej punkt wyjścia? 2. Jakie są przesłanki fenomenologicznego podejścia badawczego? 3. Czym jest kategoria świata życia codziennego (niem. Lebenswelt) i 4. W jakim zakresie kategoria ta może być pomocna przy analizowaniu współczesnej edukacji? Odnośnie do ostatniego pytania referent na podstawie swoich dotychczasowych publikacji przedstawił cztery propozycje aplikacyjnego zastosowania kategorii świata życia codziennego w badaniach pedagogicznych, a mianowicie: 1. edukacyjne preliminaria i imponderabilia, tzn. rozjaśnienie takich terminów edukacyjnych, jak „olśnienie” 
(Platońska metafora jaskini) czy „obecność” (piętno Edypa); 2. interpretacja fenomenu ufundowania, $\mathrm{np}$. poszukiwanie rozumienia tego, co duchowe, $\mathrm{w}$ tym, co materialne, czy tego, co nieograniczone, $w$ tym, co ograniczone; 3. odtworzenie aporetyczności i dialektyczności procesu rozwoju człowieka, np. immanencja versus transcendencja ludzkiego sposobu bycia, i w końcu 4. opracowanie kategorii swojskości i zadomowienia.

Po wystąpieniu odbyła się dyskusja, w której uczestnicy z jednej strony doprecyzowywali swoje rozumienie zaprezentowanych koncepcji, z drugiej natomiast zastanawiali się nad możliwościami wykorzystania kategorii stricte filozoficznych w badaniach pedagogicznych. Wyraźnie dało się odczuć przekonanie, że do zadań pedagogiki ogólnej należy zaliczyć refleksję metodologiczną i związane z nią eksplorowanie problemów i tematów pedagogicznych.

Drugim punktem programu było zwiedzanie przez uczestników spotkania znajdującej się w gmachu APS izby pamięci Marii Grzegorzewskiej, która w 1922 roku założyła w Warszawie Państwowy Instytut Pedagogiki Specjalnej, poprzednika APS, i była jego pierwszą dyrektorką. Po izbie oprowadził Jacek Kulbaka, który podzielił się wieloma interesującymi informacjami o tej wybitnej postaci polskiej pedagogiki specjalnej.

Po przerwie na obiad kontynuowano obrady. Prowadzący spotkanie przekazał głos Pawłowi Rudnickiemu i Marcinowi Starnawskiemu z Zakładu Pedagogiki Ogólnej Instytutu Pedagogiki Dolnośląskiej Szkoły Wyższej we Wrocławiu (DSW). Obaj prelegenci są w swojej uczelni koordynatorami przedmiotów ogólnopedagogicznych nauczanych na studiach I i II stopnia na kierunku pedagogika. W swoim wystąpieniu przedstawili ich charakterystykę. Ich zdaniem ogromny wpływ na miejsce, jakie współcześnie pedagogika ogólna zajmuje w DSW, wywarł jej założyciel i wieloletni rektor Robert Kwaśnica. Zgodnie z jego koncepcją pedagogiki ogólnej jako wiedzy krytycznej przewodnią ideą grupy przedmiotów ogólnopedagogicznych jest konfrontowanie potocznej wiedzy studentów z wiedzą naukową zdobywaną w trakcie studiów. Celem zajęć jest ujawnianie stereotypów myślowych kształtujących się podczas studiowania pedagogiki i pomaganie studentom $\mathrm{w}$ ich przezwyciężaniu. W związku z tym ważnym elementem (treścią) tych zajęć jest materiał autobiograficzny ich uczestników. Poza tym krytycznemu namysłowi poddawana jest obowiązująca nomenklatura pedagogiczna, $w$ tym przede wszystkim neoliberalny język biurokracji edukacyjnej na poziomie europejskim i krajowym.

Do przedmiotów ogólnopedagogicznych w DSW zalicza się: 1. wprowadzenie do pedagogiki, 2. współczesne koncepcje i systemy edukacyjne, 3. pedagogikę ogólną i 4. społeczno-ideologiczne konteksty edukacji. Referenci scharakteryzowali każdy z tych przedmiotów, a następnie prześledzili ich powiązania z innymi przedmiotami, takimi jak: teoria wychowania, socjologia wychowania, doktryny pedagogiczne, współczesne problemy socjologii, edukacja antydyskryminacyjna. $\mathrm{Na}$ koniec podzielili się swoimi refleksjami ze współpracy w ramach Zakładu Pedagogiki Ogólnej i z innymi wykładowcami. Refleksje te dotyczyły: 
- pytania o pedagogikę ogólną jako fundament wiedzy pedagogicznej,

- „trudnej” obecności teorii,

- krytyki krytyki,

- „odszufladkowania” wiedzy profesjonalnej.

Podczas dyskusji zwrócono uwagę na korzyści wynikające z zapoznania się $z$ tym, jak w innych uczelniach traktowana jest pedagogika ogólna i jak się jej naucza. Wskazano przy tym na ograniczenia, a nawet bariery instytucjonalne, takie jak: rywalizacja o przydział godzin, brak idei wiodącej i niechęć do współpracy ze strony zespołu.

W ramach kolejnego punktu programu wystąpił Mariusz Dembiński z Zakładu Metodologii Nauk o Edukacji Wydziału Studiów Edukacyjnych Uniwersytetu im. Adama Mickiewicza w Poznaniu, który przedstawił suplement do dyskusji poświęconej książce Dietricha Bennera Pedagogika ogólna. Dyskusja ta odbyła się na poprzednim spotkaniu ZPO w Bydgoszczy. Mariusz Dembiński za punkt wyjścia przyjął w swoich analizach ideę nieafirmatywnej pedagogiki ogólnej. Jego zdaniem tej właśnie idei podporząadkowana jest zarówno konstrukcja podręcznika autorstwa Bennera, jak i jego propozycja uprawiania pedagogiki ogólnej jako dyscypliny obejmującej całość subdyscyplin naukowych zajmujących się działaniem i myśleniem pedagogicznym. Nieafirmatywność tę można wyraźnie dostrzec w co najmniej dwóch zakresach: po pierwsze, $w$ dominacji pytania nad odpowiedziami $\mathrm{w}$ przedstawionych przez autora rozważaniach na temat zasad, teorii i form pedagogicznej praxis i, po drugie, w otwartej strukturze, jaką nadał swojemu opracowaniu. To ostatnie oznacza, że nie powinno ono być traktowane jako zamknięcie poszukiwania „podstawowej myśli pedagogicznej” we współczesności, lecz wprost przeciwne - jako otwarcie go i jedna z możliwych propozycji odpowiedzi.

Po krótkiej dyskusji głos zabrał Roman Leppert, który zaanonsował najnowszą książkę Romana Schulza pt. Szkice z pedagogiki ogólnej, opublikowaną przez Wydawnictwo A. Marszałka w Toruniu. Następnie zapowiedział wystąpienie Rafała Włodarczyka z Zakładu Pedagogiki Ogólnej Instytutu Pedagogiki Uniwersytetu Wrocławskiego, który przedstawił zebranym projekt zorganizowania ogólnopolskiej konferencji naukowej poświęconej koncepcjom pedagogiki ogólnej - zarówno w ujęciu historycznym, jak i systematycznym. Konferencja odbędzie się pod koniec września przyszłego roku we Wrocławiu.

Na zakończenie Roman Leppert zaanonsował mające wkrótce nastąpić otwarcie strony internetowej ZPO, która będzie platformą komunikacji w ramach zespołu i na zewnątrz, a następnie podziękował Jarosławowi Garze za gościnne przyjęcie w APS. Ogłosił również, że miejscem kolejnego spotkania ZPO, w kwietniu 2017 roku, będzie Wydział Nauk Pedagogicznych Uniwersytetu Kardynała Stefana Wyszyńskiego w Warszawie. 